\title{
Protein turnover in rats treated with Trienbolone acetate
}

\author{
BY BRIAN G. VERNON AND PETER J. BUTTERY \\ Department of Applied Biochemistry \& Nutrition, \\ University of Nottingham School of Agriculture, Sutton Bonington, \\ Loughborough, Leics
}

(Received I3 August 1976-Accepted 6 September 1976)

\footnotetext{
I. The anabolic agent Trienbolone acetate (3-0xo- 7 - $\beta$-hydroxy-4,9, 1 I-estratriene acetate) given subcutaneously to female rats increased their growth rate compared with untreated controls $(P<0.001)$.

2. The compound had little androgenic activity.

3. The fractional synthetic and fractional degradative rates of the mixed muscle proteins were smaller in the treated rats than in the control rats.
}

Generally the male mammal grows faster than the female. However, the male is often more aggressive and difficult to handle in captivity. This and other problems have led to the use of the castrate male in many animal production systems. The presence of testosterone in the male accounts for the comparatively rapid growth rate and for the development of the sexual characteristics. These two properties are termed the anabolic and androgenic characteristics respectively. For intensive animal production systems, it would be ideal if the anabolic characteristics could be retained without the androgenic activity. This ideal has led to be development of a series of synthetic compounds with anabolic activity but without significant androgenic activity. One of the currently used compounds, Trienbolone acetate, is the subject of this communication. Trienbolone acetate implants have been shown to increase markedly the growth rate of heifer beef (Best, I972; Heitzman \& Chan, I974), veal calves, bulls, castrate male lambs and castrate male pigs (Grandadam, Schield, Jobard, Dreux \& Boisson, 1975).

The deposition of protein induced after treatment with steroids has been suggested to be the result of an increase in protein synthesis coupled with a decrease in the rate of protein catabolism (Barragry, 1974). However, most studies have concentrated on isolated tissue preparations observing the production of specific proteins (see for example Florini \& Breuer, I965; Jensen \& DeSombre, 1972). The results of the data presented here would indicate that while Trienbolone acetate induced an increase in the rate of growth of female rats, its mode of action was mediated by a reduction in the rate of protein synthesis coupled with a reduction in the rate of protein degradation.

\section{MATERIALS AND METHODS}

Specific pathogen-free rats of the Wistar strain (6o-80 g initial wt) were used and allowed access to food and water ad lib. Female animals were used except for the Herschberger test (Herschberger, Shipley \& Meyer, 1953) which requires the use of 
castrate males. Rats were randomly distributed to individual metabolism cages. A I $2 \mathrm{~h}$ light-and-dark cycle was used.

Trienbolone acetate ( 3 -oxo-I 7- $\beta$-hydroxy-4,9, I I-estratriene acetate, obtained from Roussel-Uclaf, Paris) was prepared for injection by dissolving $20 \mathrm{mg}$ in $200 \mu \mathrm{l}$ ethyl acetate. Corn oil was then added to give a final concentration of Trienbolone acetate in the corn oil of $0.8 \mathrm{mg} / \mathrm{ml}$ and the mixture rotary evaporated under reduced pressure to remove the ethyl acetate. Rats were injected subcutaneously via the neck skin fold ( $80 \mu \mathrm{g}$ Trienbolone acetate/ $/ 00 \mathrm{~g}$ body wt). Control rats were given corn oil similarly treated but without the addition of Trienbolone acetate.

Fractional synthetic rates of mixed tissue proteins were determined by the continuous infusion method described by Waterlow \& Stephen (ig68) but using L-[U-14 C]tyrosine (Garlick \& Marshall, I972). L-[U-14C]tyrosine (Radiochemical Centre, Amersham, Bucks.) diluted to $2 \cdot 0 \mu \mathrm{Ci} / \mathrm{ml}$ saline, specific activity io $\mathrm{mCi} / \mathrm{mmol}$ was infused into the tail vein at a rate of $0.64 \mathrm{ml} / \mathrm{h}$ for $6 \mathrm{~h}$. At the end of the infusion, rats were killed by cervical dislocation, tissues frozen in liquid nitrogen and stored at $-20^{\circ}$ until analysed. L-tyrosine was estimated in the protein-bound fractions by homogenizing the tissue in cold trichloroacetic acid ( $100 \mathrm{~g} / \mathrm{l})$, washing the precipitate in cold trichloroacetic acid solution and then hydrolysing it for $22 \mathrm{~h}$ in $6 \mathrm{M}-\mathrm{HCl}$ at I $10^{\circ}$. The tyrosine content of the hydrolysate was determined using the method of Waalkes \& Udenfriend (1957) and the radioactivity in the tyrosine determined by trapping the ${ }^{14} \mathrm{CO}_{2}$ released on treatment of the hydrolysate with tyrosine decarboxylase (Sigma, London) in Hyamine hydroxide (Fisons Scientific, Loughborough).

The intracellular free L-tyrosine content of tissue samples was estimated by homogenizing the tissue (approximately $\mathrm{I} g$ ) in cold picric acid ( $\mathrm{I} \circ \mathrm{g} / \mathrm{l}$ ), washing the precipitate twice with cold picric acid ( $1 \circ \mathrm{g} / \mathrm{l})$ and combining the supernatants. The combined supernatants $(25 \mathrm{ml}$ ) were passed down an $8 \times 0.8 \mathrm{~cm}$ column of Dowex $2 \times 8$, 200-400 mesh resin (Bio-Rad Laboratories, California) followed by $5 \mathrm{ml} 0.02 \mathrm{M}-\mathrm{HCl}$, the effluent was collected in a round-bottomed flask, rotary evaporated to dryness at $37^{\circ}$ under reduced pressure and taken up in $2.0 \mathrm{ml}$ of distilled water. L-tyrosine and $\left[{ }^{14} \mathrm{C}\right]$ tyrosine were estimated as for the protein-bound fraction.

Fractional rates of protein degradation were determined using the $\mathrm{Na}_{2}{ }^{14} \mathrm{CO}_{3}$ method described by Millward (1970). Each rat ( ${ }_{5}$ in each treatment) received $250 \mu \mathrm{Ci}$ $\mathrm{Na}_{2}{ }^{14} \mathrm{CO}_{3}(59 \mathrm{mCi} / \mathrm{mmol})$ intraperitoneally. Three rats from each treatment were killed on days $2,4,8,11$ and 14 after the injection.

Male rats were castrated $4 \mathrm{~d}$ before they were used for the Herschberger test (Herschberger et al. 1953). They were then divided into three groups each of 6 animals. One group received Trienbolone acetate, the other testosterone (British Drug Houses, Poole, Dorset; $80 \mu \mathrm{g} / \mathrm{I} 00 \mathrm{~g}$ body wt per $\mathrm{d}$, prepared as per Trienbolone acetate) and the control group just received oil. After $\mathrm{I} 5 \mathrm{~d}$ of treatment the animals were killed and the $\mathrm{m}$. levator ani and the ventral prostate glands removed, blotted and weighed. 
Table I. Effect of Trienbolone acetate on weight gain and tissue weights (measured as a percentage of final body weight) in the rat

(Results are expressed as means \pm SEM)

\begin{tabular}{|c|c|c|c|c|}
\hline & \multicolumn{2}{|c|}{ Test $(n=6)$} & \multicolumn{2}{|c|}{ Control $(n=6)$} \\
\hline & mean & SEM & mean & SEM \\
\hline Initial (g) & $86 \cdot 3$ & $I \cdot 69$ & $86 \cdot 9$ & I.92 N.S. \\
\hline Final $(g)$ & $163 \cdot 3$ & 3.42 & $145^{\circ} 2$ & $2 \cdot 23 * * *$ \\
\hline Weight gain (g) & 77.0 & 2.59 & $58 \cdot 3$ & $1 \cdot 65 * * *$ \\
\hline Kidney & 0.99 & $0.03 \mathrm{I}$ & 0.89 & $0.02 \mathrm{I} * * *$ \\
\hline Spleen & 0.21 & O.OII & 0.25 & $0.012 * * *$ \\
\hline Liver & 4.00 & 0.12 & $4 \cdot 10$ & 0.09 N.S. \\
\hline Heart & 0.45 & 0.013 & 0.44 & 0.0I4 N.S. \\
\hline Uterus & 0.18 & 0.007 & 0.13 & $0.01 * *$ \\
\hline
\end{tabular}

Significance of difference from each group: ** $P<0.01 ; * * * P<0.001 ;$ N.S. $P>0.05$.

Table 2. Results of Herschberger analysis showing the effect of Trienbolone acetate and of testosterone in the rat

(All values are mean $\pm \operatorname{SEM}(6)$ )

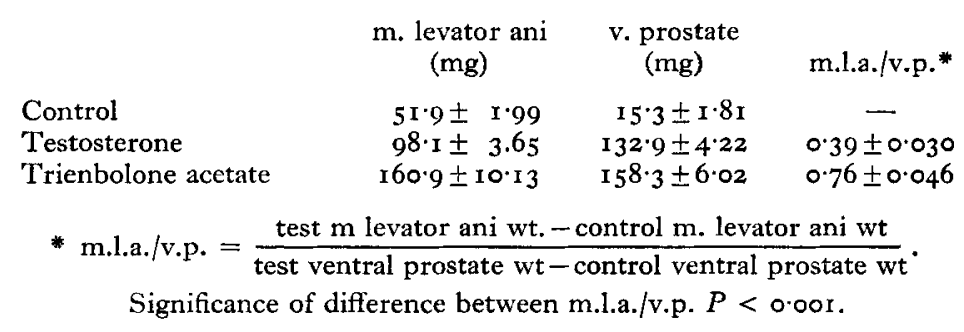

\section{RESULTS AND DISCUSSION}

The treated female rats grew significantly faster than the control rats $(P<0.001)$. The difference in growth rate was apparent within $4 \mathrm{~d}$ of commencing the Trienbolone acetate treatment. There were also differences in organ size (Table I). This increase in growth rate did not appear to be directly related to any androgenic properties the compound may have. An enlargement of the kidney seen on feeding growth promoters has been interpreted as an indication of anabolic activity rather than androgenic activity (Jelinek, Vesela \& Valova, 1964). The increase in weight of the uterus is also not consistent with significant androgenic activity (see Lobl \& Maenza, 1975).

Results from the Herschberger test (Herschberger et al. 1953) which can be used to compare the anabolic activity with the androgenic activity of a compound, also indicated the enhanced anabolic activity of the compound (Table 2).

Results from the continuous infusion experiments indicated that Trienbolone acetate reduced the fractional synthetic rate of the mixed protein of the muscle and of the heart (Table 3). There was also a similar reduction in the fractional degradative rate. In the present study we are assuming that there was an increased rate of protein deposition in the test animals. Trienbolone acetate has been reported to increase 
Table 3. Fractional synthetic rates and fractional degradative rate of mixed proteins in the tissues of the female rat treated with Trienbolone acetate

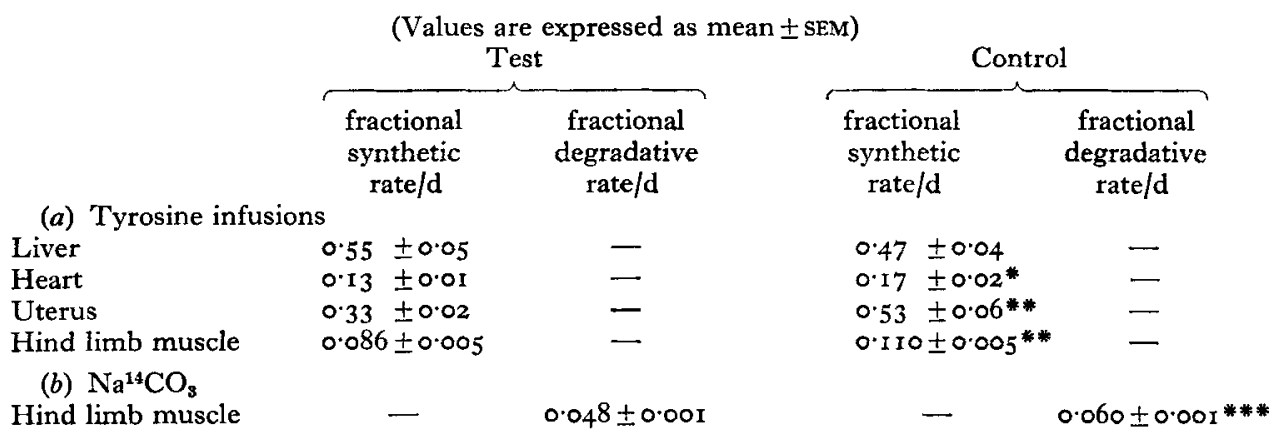

In experiment (a) fractional synthetic rates were determined using the continuous infusion technique with rats previously injected for $2 \mathrm{I} \mathrm{d}$ with Trienbolone acetate $(80 \mu \mathrm{g} / \mathrm{loo} \mathrm{g}$ body wt per d) or with corn oil; six rats in each group. In experiment $(b)$ the $\mathrm{Na}^{14} \mathrm{CO}_{3}$ technique was used to measure fractional degradative rate. Rats were again injected with $80 \mu \mathrm{g}$ Trienbolone acetate/roo $\mathrm{g}$ body wt per $\mathrm{d}$ or with corn oil. For details see text. Significant differences between test and control group given as: * $P<0.05, * * P<0.01, * * * P<0.001$.

nitrogen retention (Chan, Heitzman \& Kitchenham, 1975). The fact that the difference between the measured synthetic and degradative rates in the test and control animals did not quantitatively account for the increased growth of the treated animals is probably a consequence of the errors, both conceptual and analytical, associated with the techniques used. The observed reduction in protein synthetic rate is again not consistent with significant androgenic activity; in males mixed muscle proteins have a faster fractional synthetic rate than in females (Waterlow \& Stephen, 1967).

The simultaneous changes in the fractional synthetic and fractional degradative rates of muscle proteins accompanying changes in growth rate have been reported previously (Millward, Garlick, Nnanyelugo \& Waterlow, 1976). This reduction in the over-all rate of protein turnover in the treated animals is consistent with the increased feed-conversion efficiency noted in Trienbolone acetate-treated animals (Heitzman $\&$ Chan, 1974); the continual turnover of proteins is an energetically expensive process (see for example Buttery \& Annison, 1973). In the pig protein turnover has been calculated to account for $17 \%$ of basal metabolic rate (Garlick, Burke $\&$ Swick, I 976 ).

We wish to thank Dr N. B. Haynes for helpful discussion; Roussel-Uclaf, Paris, for the gift of Trienbolone acetate and the Science Research Council for a studentship for B.G.V. 


\section{REFERENCES}

Barragry, T. B. (1 974). Ir. Vet. $\mathcal{~ J . ~ 2 8 , ~} 28$.

Best, J. M. J. (I972). Vet. Rec. 91, 624.

Buttery, P.J. \& Annison, E. F. (I973). In The Biological Efficiency of Protein Production, p. I+I [J. W. G. Jones, editor]. London: Cambridge University Press.

Chan, K. H., Heitzman, R. J. \& Kitchenham, B. A. (1975). Br. Vet. F. 131, I70.

Florini, J. R. \& Breuer, C. B. (1965). Biochemistry, 4, I544.

Garlick, P. J. \& Marshall, I. (1972). F. Neurochem. x9, 579.

Garlick, P. J., Burke, T. L. \& Swick, R. T. (1976). Am. Y. Phys. 230, i 108.

Grandadam, J. A., Schield, J. P., Jobard, A., Dreux, H. \& Boisson, J. M. (1975). F. Anim. Sci. 4r, 969.

Herschberger, L. G., Shipley, E. G. \& Meyer, R. K. (1953). Proc. Soc. exp. Biol. Med. 83, 175.

Heitzman, R. J. \& Chan, K. H. (I974). Br. Vet. F. r3o, 532.

Jelinek, J., Vesela, H. \& Valova, B. (I964). Acta endocr. Copnh. 46, 352.

Jensen, E. V. \& DeSombre, E. R. (1972). Ann. Rev. Biochem. 4I, 203.

Lobl, R. T. \& Maenza, R. M. (1975). Biol. Reprod. 13, 255.

Millward, D. J. (1970). Clin. Sci. 39, 577.

Millward, D. J., Garlick, P. J., Nnanyelugo, D. O. \& Waterlow, J. C. (1976). Biochem. 7. 156, I85.

Waalkes, T. P. \& Udenfriend, S. (1957). F. Lab. Clin. Med. 50, 733.

Waterlow, J. C. \& Stephen, J. M. L. (1967). Clin. Sci. 33, 489.

Waterlow, J. C. \& Stephen, J. M. L. (1968). Clin. Sci. 35, 287. 